Journal: Education and Language Research Center (ELRC)

Vol. 1 No. 1, 2021

\title{
INCREASING LEARNING OUTCOMES THROUGH THE INQUIRY METHOD
}

\author{
${ }^{1}$ Arif Mustaqim, ${ }^{2}$ Ibnu Rawandhy N. Hula \\ Email: ${ }^{1}$ arifjunkies@gmail.com coauthor: ${ }^{2}$ ibnurawandi@iaingorontalo.ac.id \\ ${ }^{1}$ MA Darul Falah Sumber Gempol, Jawa Timur, ${ }^{2}$ IAIN Sultan Amai Gorontalo, Indonesia
}

\begin{abstract}
Received:

01 Oktober 2021

This study aims to determine the improvement of learning outcomes after learning with the inquiry learning model is carried out. This research method

Accepted:

17 Oktober 2021 uses Classroom Action Research with two cycles with steps, namely planning, implementing actions, observing and reflecting. The subjects of this study were MA Darul Falah Sumber Gempol Jawab Timur students. The data collected is

Published:

23 November 2021 the result of observing the implementation of learning and learning outcomes tests. Data analysis used descriptive quantitative techniques. The results of the study stated that the learning outcomes with classical completeness cycle I: $45.45 \%$, cycle II: $90.90 \%$. The data obtained show that the inquiry learning model can improve student learning outcomes in material about living a noble life by respecting parents.

Key Word Method; inquiry; learning outcomes
\end{abstract}

\section{ABSTRAK}

Penelitian ini bertujuan untuk mengetahui peningkatkan hasil belajar setelah dilaksanakan pembelajaran dengan metode pembelajaran inquiry. Metode penelitian ini menggunakan Penelitian Tindakan Kelas dengan dua siklus dengan langkah yaitu perencanaan, pelaksanaan tindakan, observasi dan refleksi. Subjek penelitian ini adalah siswa MA Darul Falah Sumbergempol. Data yang dikumpulkan adalah hasil observasi pelaksanaan pembelajaran dan tes hasil belajar. Analisis data menggunakan teknik kuantitatif dan kualitatif. Hasil penelitian menyebutkan bahwa hasil belajar dengan ketuntasan klasikal siklus I: 45,45\%, siklus II: 90,90\%. Data-data yang diperoleh menunjukkan bahwa model pembelajaran inquiry dapat meningkatkan hasil belajar siswa dalam materi tentang hidup mulia dengan menghormati orang tua

Kata Kunci: Metode; inquiry; hasil belajar

\section{PENDAHULUAN}

Dewasa ini, semakin banyak penelitian menunjukkan bahwa model pembelajaran yang dirancang untuk memenuhi kebutuhan pendidikan sudah tidak memadai lagi untuk berbagai tantangan dan kesempatan yang dihadapi siswa pada abad 21. ${ }^{1}$ Tuntutan zaman merubah karakteristik warga negara untuk menghadapi tantangan abad 21. berpikir kritis, kreatif, inovatif, bekerja sama, mampu

${ }^{1}$ Nur Hidayah, "Penggunaan Multimedia Autoplay Dalam Meningkatkan Efektivitas Pembelajaran Aqidah Akhlak Kelas Xii Madrasah Aliyah Almaarif Singosari Malang," Skripsi Universitas Islam Negeri Maulana Malik Ibrabim 53, no. 5 (2015): $1-116$. 
berkomunikasi, kolaborasi, dan memecahkan masalah untuk menopang produktivitas merupakan karakteristik abad $21 .^{2}$

Pembelajaran yang mampu menggiatkan siswa untuk berfikir secara aktif dan kreatif di dalam proses pembelajaran adalah pembelajaran dengan menggunakan model pembelajaran inquiry. ${ }^{3}$ Pembelajaran inkuiri menerapkan kepada keaktifan siswa di dalam proses pembelajaran sedangkan guru berperan sebagai fasilitator dan motivator di dalam proses pembelajaran, dan tidak menjadikan guru sebagai salah satu-satunya sumber belajar. ${ }^{4}$

Secara harfiah pembelajaran berarti proses, cara, perbuatan mempelajari dan perbuatan menjadikan orang atau makhluk hidup belajar. ${ }^{5}$ Belajar adalah suatu proses usaha yang dilakukan seseorang untuk memperoleh suatu perubahan tingkah laku yang baru secara keseluruhan sebagai hasil pengalamannya sendiri dalam interaksi dengan lingkungannya. ${ }^{6}$

Hasil belajar adalah suatu perubahan yang dialami seseorang setelah belajar, contoh dari yang tidak tahu menjadi tahu, dan dari yang tidak mengerti menjadi mengerti. ${ }^{7}$ Terjadinya perubahanperubahan tersebut mengalami tidak secara langsung terbentuk, akan tetapi melalui beberapa proses pembelajaran atau faktor-faktor yang lain yang masih berhubungan dengan kegiatan pembelajaran."Faktor-faktor yang mempengaruhi belajar siswa oleh tiga faktor utama yaitu faktor dari dalam diri siswa dan faktor dari luar siswa atau faktor lingkungan dan faktor pendekatan”.

Penelitian ini bertujuan untuk dapat mengetahui metode inquiry dapat meningkatkan hasil belajar pada pelajaran Akidah Akhlak kelas X semester ganjil di MA Darul Falah Sumbergempol Tulungagung. Pemilihan metode inquiry learning didasari oleh alasan bahwa motode ini dipandang cocok dalam pembelajaran Akidah Akhlaq, pada prakteknya peserta didik dituntun untuk mengajukan pertanyaan, melakukan penyelidikan atau eksperimen sehingga mereka secara mandiri untuk mendapatkan pengetahuan yang mereka butuhkan. Dalam motede ini, peserta didik juga diarahkan agar dapat mencari tahu sendiri materi yang disajikan dalam pembelajaran dengan cara mengajukan pertanyaan dan investigasi mandiri, ?

2 Mona Arisca, "Penerapan Model Pembelajaran Inkuiri Dapat Meningkatkan Hasil Belajar Aqidah Akhlah Pada Peserta Didik Kelas V DI MIS Masyariqul Anwar (MMA) IV,” Iain Raden Intan Lampung, 2017.

3 Ardiyansyah Purba, "Upaya Meningkatkan Hasil Belajar Siswa Pada Mata Pelajaran Akhlak Materi Dosa Besar Dengan Menggunakan Metode Mind Mapping Pada Siswa Kelas X Madrasah Aliyah Negeri Dolok Masihul Tahun Ajaran 2016/2017," Skripsi Universitas Islam Negeri Sumatera Utara Medan, 2017.

4 (Gultom et al., Penggunaan metode pembelajaran .2020)

5 Purba, "Upaya Meningkatkan Hasil Belajar Siswa Pada Mata Pelajaran Akhlak Materi Dosa Besar Dengan Menggunakan Metode Mind Mapping Pada Siswa Kelas X Madrasah Aliyah Negeri Dolok Masihul Tahun Ajaran 2016/2017."

${ }^{6}$ Asep Saepudin, "Upaya Peningkatan Hasil Belajar Akidah Akhlak Melaui Metode Sosiodrama Pada Siswa Kelas Viii Di Smp Islam Teratai Putih Global Bekasi,” Universitas Islam Negeri Syarif Hidayatullah, 2016.

${ }^{7}$ Eresia Lamajau, "Peningkatan Kemampuan Keterampilan Berbicara Siswa Kelas V SDN Sampaka Kec. Bualemo Kab. Banggai Melalui Metode Diskusi Kelompok,” Jurnal Kreatif Tadulako Online 5, no. 1 (2014): 201-11.

8 Ulfa Yunida, "Peningkatan Hasil Belajar Aqidah Akhlak Melalui Strategi Belajar Inquiry Di Kelas Xi Ma Mathla'ul Anwar Kecamatan Kedondong Kabupaten Pesawaran Tahun Ajaran 2016/2017 Skripsi," Skripsi UIN Raden Intan Lampung 58, no. 12 (2014): 7250-57, https://doi.org/10.1128/AAC.03728-14.

9 (Janita, Pembelajaran Inkuiri Dalam Meningkatkan Hasil Belajar Peserta Didik Pada Mata Pelajaran Akidah Akhlak Di Mts Ma'arif Tritunggal 2020) 
Pengertian di atas senada dengan pendapat ahli lain bahwa Inquiry learning adalah model pembelajaran yang mendorong peserta didik untuk mengajukan pertanyaan dan menarik simpulan dari prinsip-prinsip umum berdasarkan pengalaman dan kegiatan praktis. Artinya, pembelajaran ini menuntut siswa untuk mencari dan menemukan sendiri pengetahuan yang mereka butuhkan, lewat pertanyaan atau penyelidikan,. Hasil belajar adalah setiap macam kegiatan belajar menghasil kanperubahan yang khas yaitu, belajar. Hasil belajar tampak dalam suatu prestasi yang diberikan siswa, misalnya menyebutkan huruf dalam abjad secara berurutan. ${ }^{10}$ Hasil belajar siswa dapat diketahui melalui penilaian kelas. Penilaian kelas merupakan proses pengumpulan dan penggunaan informasi untuk pemberian keputusan terhadap hasil belajar siswa, berdasarkan tahapan kemajuan belajarnya sehingga didapatkan potret atau profil kemampuan siswa sesuai dengan kompetensi yang ditetapkan dalam kurikulum. Bentuk penilaian kelas yang digunakan dalam penelitian ini yaitu penilaian kinerja (perfomance), penilaian tes tertulis (paper and pen), dan penilaian sikap. ${ }^{11}$ Adapun indikator keberhasilan belajar ${ }^{12}$, seperti terlihat pada gambar ini adalah :

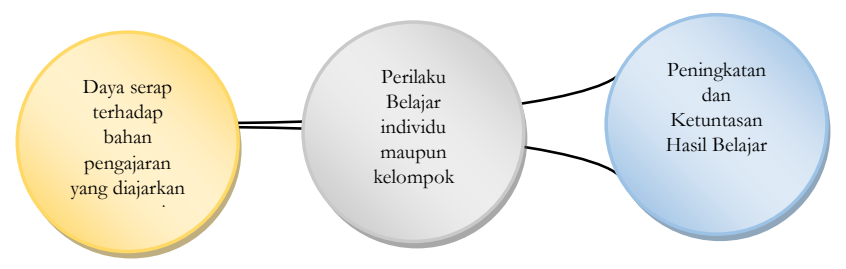

Penelitian tentang metode inquiry, telah dilakukan oleh Septimi Hartati Natalia 2019, Upaya Meningkatkan Hasil Belajar Fiqih Materi Binatang Yang Halal Dan Haram Melalui Metode Inquiry, Hasil penelitian menunjukkan bahwa: Persentaseketuntasan hasil belajar siswa secara klasikal pada kondisi awal mencapai 46,7\%. Pada siklus Imeningkat 26,6\% sehingga mencapai 73,3\%. Pada siklus II terjadi peningkatan yaitu 20\%sehingga menjadi 93,3\%. Aktivitas belajar siswa siklus I adalah 3,1 yang tergolong cukupdan meningkat pada siklus II menjadi 3,9 yang tergolong baik. Dengan demikian dapat disimpulkan bahwa hasil belajar siswa pada materi binatang yang halal dan haram dapat meningkat dengan menerapkan metode inquiry di kelas V MIS Darul Ma’arif Kabupaten Simeulue.

Penulis tertarik meneliti tentang metode inquiry, karena metode ini belum pernah digunakan pada materi tertentu pada mata pelajaran Akidah Akhlaq, terlibih lagi para siswa kelas X belum lebih banyak mendapat metode yang monoton, kurang aktif, dan tidak mengarahkan kepada kemandirian belajar, sehingga dalam aspek penguasaan materi siswa cenderung kurang reaktif dalam merespon pertanyaan guru baik lisan maupun tulisan, kalaupun ada hanya beberapa siswa yang mampu menjawabnya.

Dalam proses pembelajaran, siswa menafsirkan dan menganalisis data, memberikan bukti, mengkomunikasikan ide, memberikan penjelasan alternatif, dan membenarkan kesimpulan. ${ }^{13}$ Demikian juga, setiap diberi kesempatan bertanya tidak satupun siswa yang berani untuk bertanya dan mau menunjukkan kemampuan untuk menunjukkan ide atau gagasan dan siswa lebih cendrung menghafal

${ }^{10}$ Maisaroh and Rostrieningsih, "Peningkatan Hasil Belajar Siswa Dengan Menggunakan Metode Pembelajaran Active Learning Tipe Quiz Team Pada Mata Pelajaran Keterampilan Dasar Komunikasi Di SMK Negeri 1 Bogor,” Jurnal Ekonomi Dan Pendidikan 7, no. 2 (2012): 157-72, https://doi.org/10.21831/jep.v7i2.571.

11 T. H. Agustanti, "Implementasi Metode Inquiry Untuk Meningkatkan Hasil Belajar Biologi," Jurnal Pendidikan IPA Indonesia 1, no. 1 (2012): 16-20, https://doi.org/10.15294/jpii.v1i1.2007.

12 Arisca, "Penerapan Model Pembelajaran Inkuiri Dapat Meningkatkan Hasil Belajar Aqidah Akhlah Pada Peserta Didik Kelas V DI MIS Masyariqul Anwar (MMA) IV."

13 
materi dalam proses pembelajaran. Untuk memupuk kreativitas siswa dalam pembelajaran Akidah Akhlak, terutama menyangkut kemampuan cara berpikir siswa, maka perlu suatu metode pembelajaran yang mendorong siswa menjadi pemikir yang baik, yang mampu memberikan banyak alternatif jawaban terhadap suatu permasalahan.

Kondisi seperti itu tidak akan meningkatkan kemampuan siswa dalam memahami mata pelajaran Akidah Akhlak dan tidak melatih siswa untuk berpikir secara kritis Akibatnya nilai akhir yang dicapai siswa tidak seperti yang diharapkan. Berdasarkan pengamatan, siswa kelas $\mathrm{X}$ hasil belajarnya masih tergolong rendah, dari data yang diperoleh peneliti di sekolah tersebut hasil belajar siswa pada materi berbakti kepada orang tua dan guru yang belum tuntas 15 orang atau 68,18\% siswa mendapatkan nilai dibawah standar ketuntasan minimum (KKM), dan 31,81\% diantaranya memperoleh nilai diatas standar ketuntasan minimum (KKM). Rata-rata nilai ulangan harian Akidah Akhlak siswa yang didapatkan sebesar 62, sedangkan standar ketuntasan yang telah ditetapkan sekolah adalah 75 .

Terlihat jelas bahwa rendahnya hasil belajar mayoritas siswa pada materi tersebut perlu ditingkatkan. Dengan meningkatkan kemampuan berpikir kritis siswa dalam menanggapai persoalan maka akan meningkat juga hasil belajar siswa. Sehingga penelitian ini tidak saja berupaya meningkatkan hasil belajar, namun berorietasi pada upaya mengetahui apakah model pembelajaran inquiry learning dapat meningkatkan hasil belajar pada materi "berbakti kepada orang tua dan guru" bagi siswa kelas X di MA Darul Falah Sumbergempol Tulungagung.

\section{METODE}

Penelitian ini merupakan penelitian tindakan kelas (PTK) yang bertempat di kelas X MA Darul Falah sumbergempol, tulungagung. Subjek penelitian sebanyak 22 siswa, Data dikumpulkan melalui test dan nontest melalui observasi dan dokumentasi. Data selanjutnya disajikan, direduksi dan disimpulkan untuk menjawab permasalahan apakah penerapan metode inquiry dapat meningkatkan hasil belajar siswa. Teknis analisis data dilakukan dengan pemberian preetest dan postest, dengan dua siklus, model Kemmis and Taggart. Untuk mengetahui tingkat kemampuan siswa yang diperoleh dari hasil tes belajar menggunakan rumus:

$\mathrm{PPH}=\mathrm{B} \times 100 \% \mathrm{~N}$

PPH : Persentase Penilaian Hasil

B : Skor yang diperoleh

$\mathrm{N}$ : Jumlah Skor Maksimum

\section{Kriteria :}

$0 \%<\mathrm{PPH}<80 \%$ siswa belum tuntas

dalam belajar

$80 \%>\mathrm{PPH}<100 \%$ siswa sudah tuntas

\section{HASIL PEMBAHASAN}

Hasil penelitian diuraikan dalam tahapan yang berupa siklus-siklus pembelajaran yang dilakukan dalam proses belajar mengajar di kelas. Namun untuk mendapatkan data perbandingan penelitian terlebih dahulu melakukan preetest sebelum kegiatan pengajaran diberikan agar dapat diketahui persentase keberhasilan penerepan metode inquiry.

Tabel 1. Preetest Ketuntasan Belajar Siswa

\begin{tabular}{llll}
\hline Ketuntasan Belajar siswa & Kategori & Banyak siswa & Persentase \\
0\% PPH 75\% & Tidak tuntas & 16 & $72,73 \%$ \\
75\% PPH 100\% & tuntas & 6 & $22,27 \%$ \\
Jumlah & & $\mathbf{2 2}$ & $\mathbf{1 0 0} \%$ \\
\hline
\end{tabular}


Dari data di atas, kelas X MA Darul Falah belum dapat dikatakan tuntas karena persentase ketuntasan klasikalnya belum mencapai $80 \%$. Siswa yang tuntas hanya berjumlah 6 orang dengan persentase ketuntasan klasikalnya 22,27\%. Sedangkan siswa yang tidak tuntas berjumlah 16 orang dengan persentase $72,73 \%$ dan rata-rata nilai siswa adalah 62 .

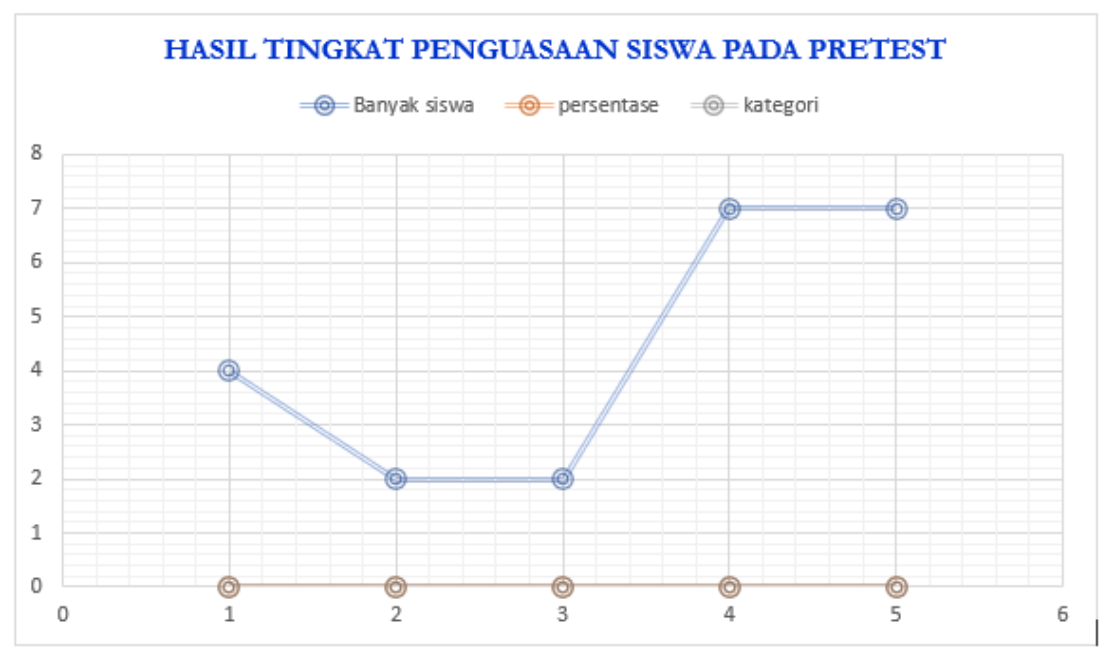

\section{Diagram 1: Tingkat penguasaan siswa pada pretest}

Data tabel dan diagram di atas menunjukkan bahwa kemampuan siswa masih dalam kategori rendah dan sangat rendah dalam memahami soal materi berbakti kepada orang tua. Siswa masih mengalami kesulitan dalam menyelesaikan soal-soal mengenai materi berbakti kepada orang tua yang diberikan guru. Langkah selanjutnya melakukan penerapan metode inquiry dalam dua siklus sebagaimana pemaparan berikut ini:

\section{Perencanaan (1)}

a) Permintaan izin dari Kepala Sekolah di Madrasah Aliyah Darul Falah Sumbergempol Tulungagung

b) Mengadakan observasi untuk mengidentifikasi permasalahan yang perlu segera diatasi.Tahap ini peneliti melakukan observasi pada pembelajaran, wawancara dengan rekan guru dan siswa.

c) Membuat lembar observasi bagi guru dan siswa untuk melihat proses pembelajaran dengan menggunakan model pembelajaran inquiri.

\section{Tindakan (2)}

a) Menyajikan materi sesuai dengan siklus dan RPP

b) Mempelajari materi pada siklus I, II, dengan menggunakan atau menerapkan model inquiri learning

c) Memberikan kesempatan kepada siswa untuk lebih berinteraksi, aktif, kreatif, dan berinovasi dalam proses pembelajaran.

d) Mengamati setiap kegiatan siswa dalam proses pembelajaran

e) Siswa diberikan waktu untuk mengulas atau mengulangi materi yang baru saja dipelajari secara bersama-sama.

f) Menciptakan suasana belajar yang menyenangkan

\section{Refleksi (3)}

a. Mempertahankan kinerja guru yang sudah baik disiklus I untuk tetap dilakukan ke siklus II

b. Meningkatkan bimbingan dan pengawasan pada saat peserta didik melakukan diskusi dalam kelompok

c. Memberikan motivasi dan apersepsi kepada siswa sebelum memulai proses pembelajaran 
Data siklus I, menunjukkan bahwa terdapat peningkatan hasil belajar pada siswa dengan nilai rata-rata 72,18 dan dengan ketuntasan klasikal sebesar 45,45\%. Maka dapat diambil kesimpulan dibandingkan dengan pre test yang diberikan pada awal pertemuan terdapat peningkatan pada hasil belajar siswa walaupun belum mencapai kriteria ketuntasan maksimum yang ditetapkan yaitu 75 . oleh karena itu guru melakukan perbaikan seperti menanyakan secara langsung kepda siswa yang masih mendapatkan nilai rendah sedangkan dari guru sendiri melakukan perbaikan dengan meningkatkan kualitas aktivitas mengajar selama kegiatan belajar mengajar (KBM) semua ini bertujuan untuk meningkatkan hasil belajar siswa agar hasil belajar siswa sesuai dengan KKM yang telah ditetapkan.

Tabel 2. Siklus 1 Ketuntasan Belajar Siswa

\begin{tabular}{llll}
\hline Ketuntasan Belajar siswa & Kategori & Banyak siswa & Persentase \\
\hline $0 \%$ PPH 75\% & Tidak tuntas & 12 & $54,54 \%$ \\
\hline 75\% PPH 100\% & tuntas & 10 & $45,45 \%$ \\
\hline Jumlah & & $\mathbf{2 2}$ & $\mathbf{1 0 0 \%}$ \\
\hline
\end{tabular}

Data di atas, menunjukkan bahwa kelas X MA Darul Falah belum dapat dikatakan tuntas karena persentase ketuntasan klasikalnya belum mencapai $80 \%$. Siswa yang tuntas hanya berjumlah 10 orang dengan persentase ketuntasan klasikalnya 45,45\%. Sedangkan siswa yang tidak tuntas berjumlah 12 orang dengan persentase $54,54 \%$ dan rata-rata nilai siswa adalah 73,18 .

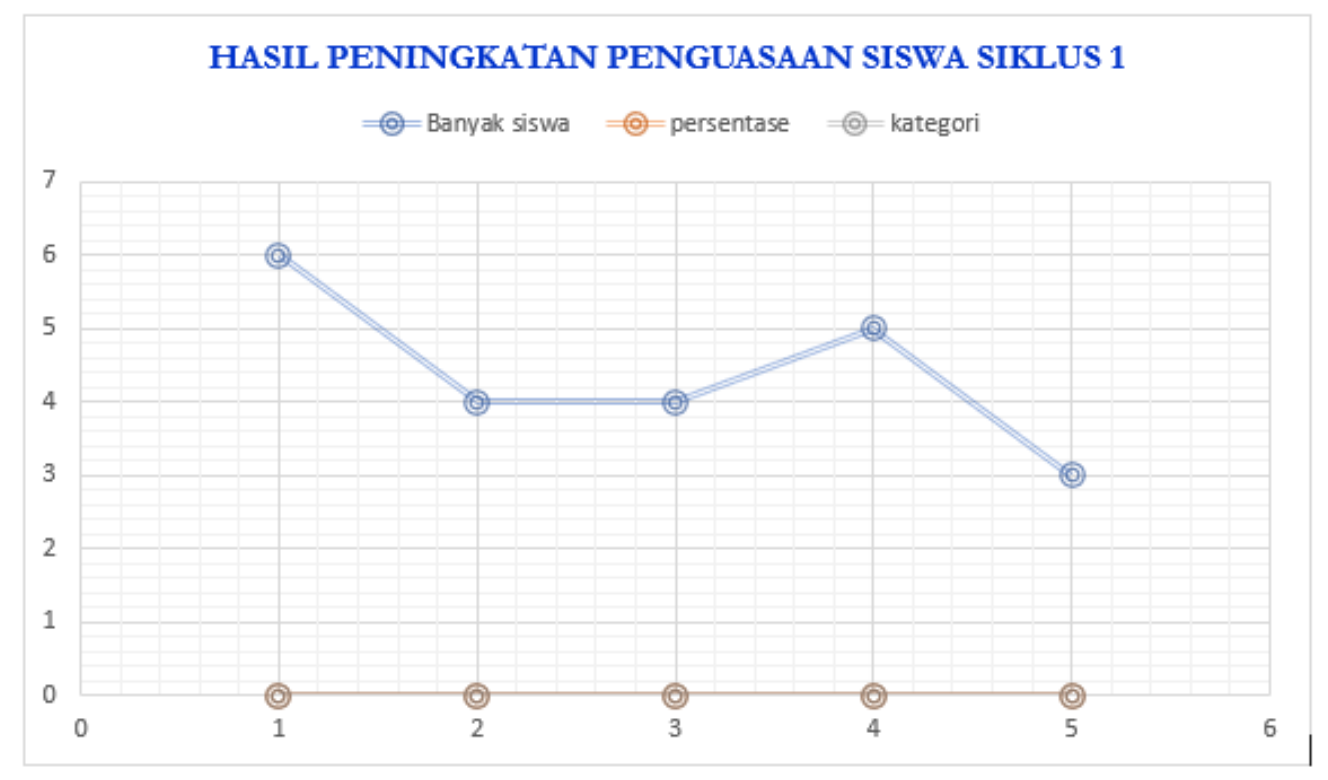

Diagram 2: Tingkat penguasaan siswa pada posttest

Dari data di atas menunjukkan bahwa kemampuan siswa masih dalam kategori sedang dalam memahami soal materi hidup mulia menghormati orang tua dan guru. Siswa masih mengalami kesulitan dalam menyelesaikan soal-soal mengenai materi "hidup mulia dengan menghormati orang tua dan guru" yang diberikan guru.

\section{a) Tahap pengamatan}

Pengamatan dilakukan oleh peneliti saat pelajaran sedang berlangsung, pengamatan ini dimaksudkan untuk mendokumentasikan dengan mencatat segala sesuatu yang berkaitan dengan 
pelaksanaan pembelajaran dengan menggunakan formal observasi. Adapun hasil observasi siklus I sebagai berikut :peserta didik menggunakan model pembelajaran inquiri, namun dalam pelaksanaannya belum menghasilkan pelaksanaan yang maksimal, ini terjadi di saat pembentukan kelompok terjadi kegaduhan karena belum di bentuk kelompok ahli, selain itu presentasi materi setiap kelompok belum memuaskan. Alokasi waktu kurang maksimal, siswa kurang aktif dalam pembelajaran, sehingga dapat disimpulkan pelaksanaan proses belajar dengan menggunkan model inquiri belum dapat menghasilkan proses belajar yang dapat memuaskan.

\section{b. Refleksi siklus I}

Pada tindakan I ini penggunaan model pembelajaran inquiri dalam mengajarkan pada materi menghormati orang tua dan guru belum sempurna sesuai dengan yang diharapkan. Analisis terhadap observasi dijadikan sebagai bahan untuk menentukan tindakan selanjutnya. Setelah diadakan refleksi oleh guru maka pada pertemuan selanjutnya guru harus lebih: 1) Mempertahankan kinerja guru yang sudah baik disiklus I untuk tetap dilakukan ke siklus II, 2) Meningkatkan bimbingan dan pengawasan pada saat peserta didik melakukan diskusi dalam kelompok, 3) Memberikan motivasi dan apersepsi kepada siswa sebelum memulai proses pembelajaran.

Tabel 3. Siklus 2 Ketuntasan Belajar Siswa

Ketuntasan Belajar siswa Kategori Banyak siswa Persentase

\begin{tabular}{llll}
\hline 0\% PPH 75\% & Tidak tuntas & 2 & $9,09 \%$ \\
\hline 75\% PPH 100\% & tuntas & 20 & $90,99 \%$ \\
\hline Jumlah & & $\mathbf{2 2}$ & $\mathbf{1 0 0 \%}$
\end{tabular}

Data siklus II di atas menunjukkan adanya kenaikan yang cukup siginifikas, yang ditandi dengan 9,09\% siswa yang belum dikatakan tuntas. Sehingga peningkatan persentase ketuntasan klasikal meningkat dari siklus I sebesar $45.45 \%$ dan meningkat pada siklus II ini menjadi $90.99 \%$.

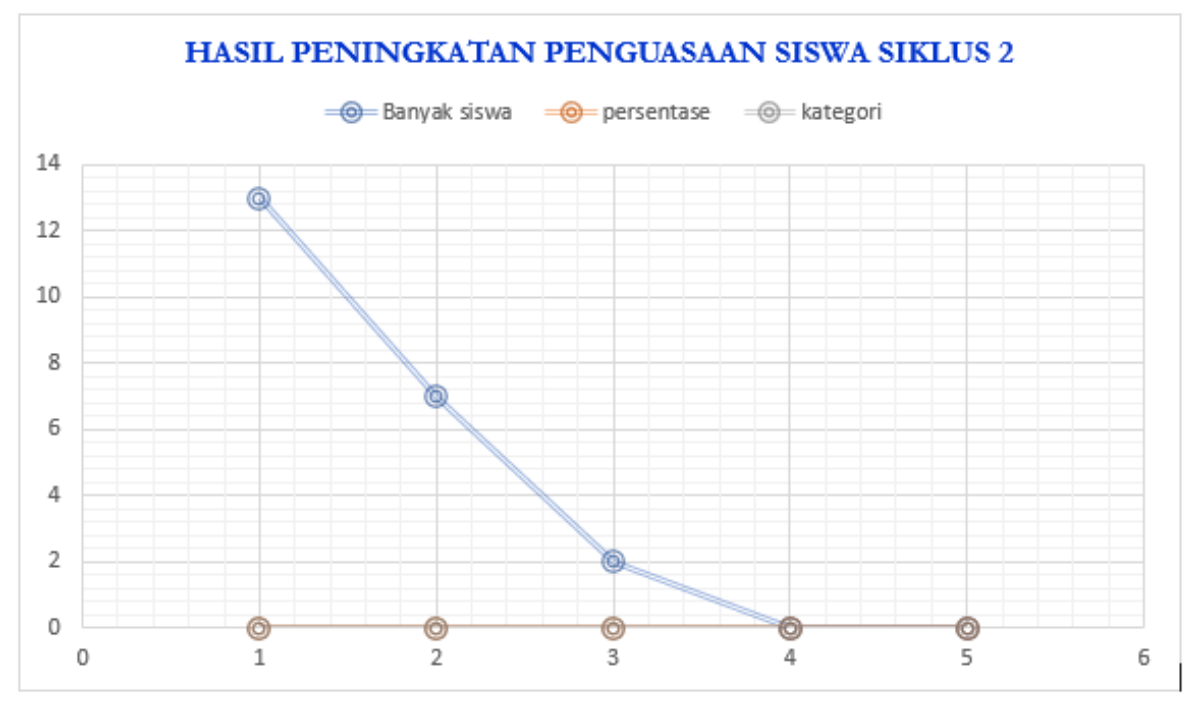

Diagram 3: Tingkat penguasaan siswa pada postest 
Secara umum pelaksanaan tindakan sudah sesuai dengan skenario pembelajaran yang telah dibuat. Semua tahapan kegiatan dalam skenario pembelajaran telah dilaksanakan dengan sempurna oleh guru. Hanya masih ada sedikit kelemahan- kelemahan pada pihak siswa yaitu ada beberapa siswa yang belum mampu menyelesaikan soal. Hasil observasi yang dilakukan oleh peneliti menunjukkan bahwa pembelajaran metode inquiry sudah mendapatkan hasil yang lebih baik. Pada siklus II ini hanya 9,09\% siswa yang belum dikatakan tuntas. Sehingga peningkatan persentase ketuntasan klasikal meningkat dari siklus I sebesar 45.45\% dan meningkat pada siklus II ini menjadi 90.99\%.

Sedangkan hasil pengamatan yang dilakukan terhadap guru pada siklus II ini dinyatakan sangat baik. sehingga yang menjadi tujuan penelitian ini untuk meningkatkan hasil belajar siswa dengan metode inquiry telah tercapai, sehingga tidak perlu dilanjutkan pada siklus berikutnya.Sedangkan hasil pengamatan yang dilakukan terhadap guru pada siklus II ini dinyatakan sangat baik. sehingga yang menjadi tujuan penelitian ini untuk meningkatkan hasil belajar siswa dengan metode inquiry telah tercapai, sehingga tidak perlu dilanjutkan pada siklus berikutnya:

Tabel 4. Perbandingan Nilai hasil belajar siswa pada setiap siklus

\begin{tabular}{|c|c|c|c|c|}
\hline No & Pencapaian Hasil belaiar & Pretes & Siklus I & Siklus II \\
\hline 1. & Jumlah siswa yang tuntas & 6 & 10 & 20 \\
\hline 2. & Nilai rata-rata & 62 & 73,44 & 89,09 \\
\hline 3. & Persentasi ketuntasan & $27,27 \%$ & $45,45 \%$ & $90,90 \%$ \\
\hline
\end{tabular}

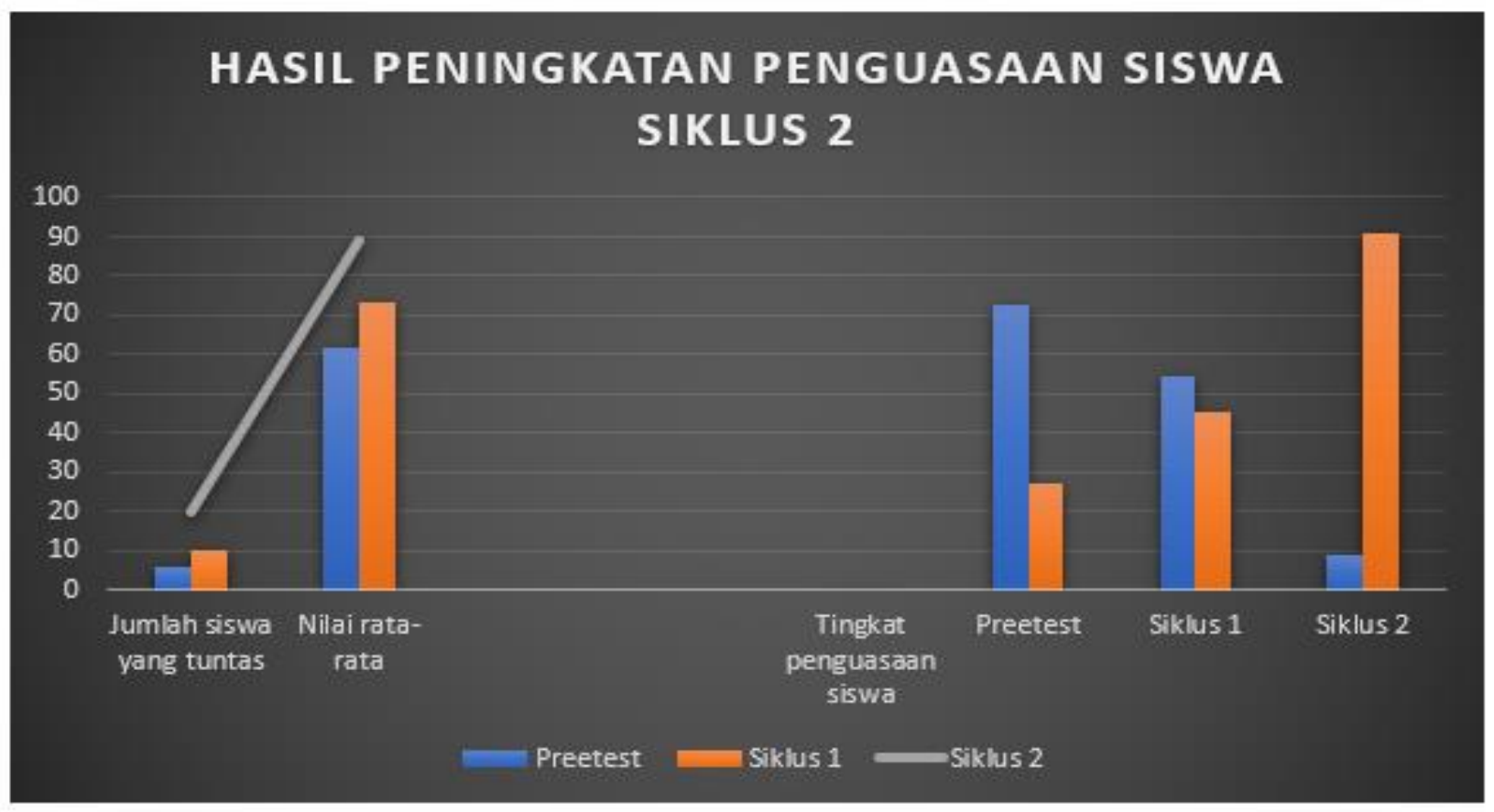

Data di atas, dapat dilihat hasil tes awal pada materi hidup mulia dengan menghormati orang tua dan guru masih rendah dengan presentase $27,27 \%$, nilai rata-rata 62 . Peneliti melakukan peningkatan dengan menggunakan metode inquiry, pada siklus I hasilnya ada peningkatan persentasi ketuntasan 45,455, nilai rata-rata 73,44. Namun ketuntasan belajar masih rendah. Pada siklus II 
terjadi peningkatan siknifikan yaitu 90,90\% dengan rata-rata 89,09, sehingga secara klasikal telah mencapai ketuntasan

Setelah melihat dan menganalisis data di atas, dapat diambil hasil akhir berupa apa yang yang telah dilakukan oleh peneliti dalam menyampaikan materi hidup mulia dengan menghormati orang tua dan guru dengan menggunakan metode inquiry ternyata mampu meningkatkan hasil belajar siswa. Dari data menyatakan bahwa dengan menggunakan metode inquiry hasil belajar siswa siswa meningkat.

\section{PENUTUP}

Berdasarkan pemaparan di atas, maka dapat disimpulkan bahwa metode pembelajaran inquiry dapat meningkatkan hasil belajar siswa. Sedangkan metode inquiry bersifat dinamis dan harus menyesuaikan dengan konsep diajarkan. Bagian penting dari metode mensyaratkan bahwa siswa diberi kesempatan untuk mengeksplorasi ide, data, atau konsep sebelum penjelasan formal terjadi. Penelitian ini berimplikasi pada meningkatnya hasil belajar siswa kelas X MA Darul Falah pada materi Aqidah Akhlak, sehingga dapat diterapkan pada tema-tema lain yang secara eksplisit menanamkan penilaian di dalam setiap fase pelajaran.

\section{DAFTAR PUSTAKA}

Agustanti, T. H. "Implementasi Metode Inquiry Untuk Meningkatkan Hasil Belajar Biologi." Jurnal Pendidikan IPA Indonesia 1, no. 1 (2012): 16-20. https://doi.org/10.15294/jpii.v1i1.2007.

Arisca, Mona. "Penerapan Model Pembelajaran Inkuiri Dapat Meningkatkan Hasil Belajar Aqidah Akhlah Pada Peserta Didik Kelas V DI MIS Masyariqul Anwar (MMA) IV.” Iain Raden Intan Lampung, 2017.

Gultom, Dwi wulandari. "Penggunaan Metode Pembelajaran." Skripsi UIN Sulthan Thaha Saifudin Jambi, 2020.

Hidayah, Nur. "Penggunaan Multimedia Autoplay Dalam Meningkatkan Efektivitas Pembelajaran Aqidah Akhlak Kelas Xii Madrasah Aliyah Almaarif Singosari Malang." Skripsi Universitas Islam Negeri Maulana Malik Ibrabim 53, no. 5 (2015): 1-116.

Janita, Bella. "Penerapan Model Pembelajaran Inkuiri Dalam Meningkatkan Hasil Belajar Peserta Didik Pada Mata Pelajaran Akidah Akhlak Di Mts Ma'arif Tritunggal Lampung Timur.” UIN Raden Intan Lampung, 2020.

Lamajau, Eresia. "Peningkatan Kemampuan Keterampilan Berbicara Siswa Kelas V SDN Sampaka Kec. Bualemo Kab. Banggai Melalui Metode Diskusi Kelompok.” Jurnal Kreatif Tadulako Online 5, no. 1 (2014): 201-11.

Maisaroh, and Rostrieningsih. "Peningkatan Hasil Belajar Siswa Dengan Menggunakan Metode Pembelajaran Active Learning Tipe Quiz Team Pada Mata Pelajaran Keterampilan Dasar Komunikasi Di SMK Negeri 1 Bogor." Jurnal Ekonomi Dan Pendidikan 7, no. 2 (2012): 15772. https://doi.org/10.21831/jep.v7i2.571.

Purba, Ardiyansyah. "Upaya Meningkatkan Hasil Belajar Siswa Pada Mata Pelajaran Akhlak Materi Dosa Besar Dengan Menggunakan Metode Mind Mapping Pada Siswa Kelas X Madrasah Aliyah Negeri Dolok Masihul Tahun Ajaran 2016/2017." Skripsi Universitas Islam Negeri Sumatera Utara Medan, 2017.

Saepudin, Asep. "Upaya Peningkatan Hasil Belajar Akidah Akhlak Melaui Metode Sosiodrama Pada Siswa Kelas Viii Di Smp Islam Teratai Putih Global Bekasi." Universitas Islam Negeri Syarif Hidayatullah, 2016. 
Yunida, Ulfa. "Peningkatan Hasil Belajar Aqidah Akhlak Melalui Strategi Belajar Inquiry Di Kelas Xi Ma Mathla'ul Anwar Kecamatan Kedondong Kabupaten Pesawaran Tahun Ajaran 2016/2017 Skripsi." Skripsi UIN Raden Intan Lampung 58, no. 12 (2014): 7250-57. https://doi.org/10.1128/AAC.03728-14.

Agustanti, T. H. "Implementasi Metode Inquiry Untuk Meningkatkan Hasil Belajar Biologi." Jurnal Pendidikan IPA Indonesia 1, no. 1 (2012): 16-20. https://doi.org/10.15294/jpii.v1i1.2007.

Arisca, Mona. "Penerapan Model Pembelajaran Inkuiri Dapat Meningkatkan Hasil Belajar Aqidah Akhlah Pada Peserta Didik Kelas V DI MIS Masyariqul Anwar (MMA) IV.” Iain Raden Intan Lampung, 2017.

Gultom, Dwi wulandari. "Penggunaan Metode Pembelajaran." Skripsi UIN Sulthan Thaha Saifudin Jambi, 2020.

Hidayah, Nur. "Penggunaan Multimedia Autoplay Dalam Meningkatkan Efektivitas Pembelajaran Aqidah Akhlak Kelas Xii Madrasah Aliyah Almaarif Singosari Malang." Skripsi Universitas Islam Negeri Maulana Malik Ibrabim 53, no. 5 (2015): 1-116.

Janita, Bella. "Penerapan Model Pembelajaran Inkuiri Dalam Meningkatkan Hasil Belajar Peserta Didik Pada Mata Pelajaran Akidah Akhlak Di Mts Ma'arif Tritunggal Lampung Timur." UIN Raden Intan Lampung, 2020.

Lamajau, Eresia. "Peningkatan Kemampuan Keterampilan Berbicara Siswa Kelas V SDN Sampaka Kec. Bualemo Kab. Banggai Melalui Metode Diskusi Kelompok." Jurnal Kreatif Tadulako Online 5, no. 1 (2014): 201-11.

Maisaroh, and Rostrieningsih. "Peningkatan Hasil Belajar Siswa Dengan Menggunakan Metode Pembelajaran Active Learning Tipe Quiz Team Pada Mata Pelajaran Keterampilan Dasar Komunikasi Di SMK Negeri 1 Bogor.” Jurnal Ekonomi Dan Pendidikan 7, no. 2 (2012): 15772. https://doi.org/10.21831/jep.v7i2.571.

Purba, Ardiyansyah. "Upaya Meningkatkan Hasil Belajar Siswa Pada Mata Pelajaran Akhlak Materi Dosa Besar Dengan Menggunakan Metode Mind Mapping Pada Siswa Kelas X Madrasah Aliyah Negeri Dolok Masihul Tahun Ajaran 2016/2017.” Skripsi Universitas Islam Negeri Sumatera Utara Medan, 2017.

Saepudin, Asep. "Upaya Peningkatan Hasil Belajar Akidah Akhlak Melaui Metode Sosiodrama Pada Siswa Kelas Viii Di Smp Islam Teratai Putih Global Bekasi." Universitas Islam Negeri Syarif Hidayatullah, 2016.

Yunida, Ulfa. "Peningkatan Hasil Belajar Aqidah Akhlak Melalui Strategi Belajar Inquiry Di Kelas Xi Ma Mathla'ul Anwar Kecamatan Kedondong Kabupaten Pesawaran Tahun Ajaran 2016/2017 Skripsi." Skripsi UIN Raden Intan Lampung 58, no. 12 (2014): 7250-57. https://doi.org/10.1128/AAC.03728-14. 